\title{
LOS DAÑOS CAUSADOS POR TERCEROS EN BIENES DE DOMINIO PUBLICO DE LAS ENTIDADES LOCALES
}

352.711

por

José-Ramón Rodríguez-Sabugo Fernández

He examinado con mucha atención el comentario monográfico publicado por Nemesio Rodrfguez Moro en el número 191 de esta REvisTa, correspondiente al período julio-septiembre del pasado año 1976, con el mismo título que se encabeza este comentario y referente a una sentencia de 17 de abril de 1975 (Aranzadi 2.556) sobre un caso del Ayuntamiento de La Unión (Murcia), declarando «la responsabilidad de la empresa $\mathrm{X}$ por daños causados en el cementerio municipal como consecuencia de la rotura del pantano de la mina $\mathrm{B}$ a efectos de su explotación, así como su obligación de repararlo, reponiendo la totalidad de los elementos dañados al estado que tenían cuando ocurrió el suceso, o, en su defecto, llegado el caso, satisfacer la indemnización correspondiente al coste de dichas obras y trabajos"; acuerdo del Ayuntamiento de La Unión (Murcia) que fue anulado por la Sala de Alicante y por el Tribunal Supremo en la citada sentencia de 17 de abril de 1975, declarando "la incompetencia de la Corporación para entender en materia propia de los Tribunales de la Jurisdicción civil, cual es la de responsabilidad por daños causados por un particular a los bienes de aquélla, aunque sean de dominio público, como derivada del artículo 1.902 del Código civil, al no existir una norma específica que aun de modo excepcional atribuya a 
aquélla la facultad de resarcirse sin previo pronunciamiento de los Tribunales; normas que no existen en casos como el contemplado ni pueden derivarse de las facultades de intervención otorgadas por los artículos $10^{\circ}$ y $5 .^{\circ}$ del Reglamento de Servicios, cuyos presupuestos obviamente no concurren en el caso y tampoco con las normas relativas a la autotutela del estado posesorio, según el artículo 404 de la Ley de Régimen local, que no comprende las facultades para pronunciar una reparación de daños...».

Hace Nemesio Rodrf́fuez Moro un estudio sobre los bienes de dominio público que están declarados por las leyes inalienables, imprescriptibles e inembargables y no sujetos a tributación, así como a recuperar la posesión perdida, desahuciar a quien indebidamente la ocupe e imponer las sanciones oportunas; el reconocimiento de la facultad de policía general a la Administración, y que cabe hablar de una policía de conservación de los bienes de dominio público; cita la opinión de Otto MAYER en defensa de que cuando la Administración actúa en relación con los bienes de dominio público lo hace conforme al régimen jurídico de Derecho público; y termina citando una aplicación concreta de las facultades de las Corporaciones locales de exigir en todo aprovechamiento especial en obras e instalaciones municipales el coste total de los repetidos gastos de reconstrucción, arreglo y conservación, que es el autorizado por el artículo 445 de la Ley de Régimen local; para terminar manifestandð̋: "De manera que si en tales casos en que se produce una destrucción de las obras e instalaciones municipales la Administración municipal ha de llevar a cabo por vía administrativa la reconstrucción o reparación y exigir del obligado el importe de los gastos ocasionados, resulta patente que en otros casos similares en que pueda producirse una destrucción o daños en la cosa pública se exija por la misma Administración la reparación con los medios jurídicos propios de aquélla que el legislador le ha querido otorgar como poder".

Voy a examinar primero una sentencia de la Sala de lo Contencioso-administrativo de la Audiencia Territorial de La Coruña en un caso de aplicación del artículo 445 de la Ley de Régimen local, en que la indicada Sala desestima la pretensión de un Ayuntamiento de cobrar en vía administrativa los daños causados a un bien público, en la que los correspondientes considerandos mantienen parecidos postulados que la mantenida por el Tribunal Supremo, la citada del Ayuntamiento de La Unión de 17 de abril, 
y posteriormente transcribiremos la sentencia del Tribunal Supremo en que reconce que el acuerdo del Ayuntamiento fue adoptado dentro de las facultades que le reconocen las disposiciones administrativas; y por último examinaré, a la vista de los correspondientes preceptos legales de aplicaçión, la sentencia del Tribunal Supremo de 17 de abril de 1975.

Los considerandos de la Sala de lo Contencioso-administrativo de la Audiencia de La Coruña, de fecha 23 de noviembre de 1961, dicen lo siguiente:

PRIMER Considerando: Que habiéndose dictado por el Ayuntamiento de Ribadeo, aquí demandado en 28 de septiembre de 1960, resolución por la cual se acordó requerir a la empresa $\mathrm{X}$ para que procediera a la reparación de la acera, calzada y alcantarillado de 80 metros de la calle de San Roque de dicha ciudad, deterioradas, a juicio del Ayuntamiento, como consecuencia del rodaje y parada de autobuses de la empresa citadí en dicha zona de la calle, en la cual hasta el $1 .^{\circ}$ de dicho mes se halla sita la administración de la empresa, y manteniendo tal acuerdo por el resolutorio de la reposición de 20 de diciembre siguiente, se promueve, en este proceso, recurso contra tales resoluciones con base en que el Ayuntamiento carece de competencia, por razón de la materia, para dictarlas, al cual se opone el Ayuntamiento alegando, en esencia, que su competencia viene fundada en las facultades de policía que le concede la ley para velar por la conservación de las vías municipales y para exigir la reparación o indemnización de los daños causados en ellas cuando sobre las mismas se ejerce un aprovechamiento o uso especial, como afirma que es el que utilizó la em. presa recurrente al ocupar la acera y vía de referencia con autobuses, equipajes y bultos durante largos estacionamientos y a veces privativamente, con limitación de uso de los demás vecinos.

SEgundo considerando: Que, concretado así el problema litigioso para su resolución, es necesario previamente sentar que los daños ocasionados por la acción u omisión de una persona en el patrimonio de un tercero con el cual no se está ligado por vínculo contractual alguno, constituyen el fundamental supuesto de hecho que da actuación a la doctrina de la responsabilidad excontractual y genera la acción de indemnización de daños y perjuicios, regida por los artículos 1.902 y siguientes del Código civil, cuyo reconocimiento corresponde exclusivamente a la Jurisdicción civil, por ser la única competente para resolver las cuestiones fundadas en normas de Derecho civil, y por ello la Administración en tal supuesto, al igual que siempre que se mueva en el campo del Derecho común, carece, como señala el Derecho de conflictos de 21 de mayo de 1955, de prerrogativas y no puede decidir por sí, constituyéndose en juez y parte, las contiendas o conflictos con los particulares, no teniendo más camino para dirimirlos que 
acudir a la vía procesal para que el Tribunal ordinario decida con arreglo a Derecho la prestación de que se trate y si, contraviniendo tal orden legal o invadiendo atribuciones típicamente judiciales, resuelve por su propio imperio la cuestión debatida, el acto en que así lo acuerde incide en nulidad de pleno derecho por defecto de competencia objetiva, sin que tal doctrina suponga, en forma alguna, negar las indudables facultades que a los Ayuntamientos les compete en materia de policía de las vías municipales, pues todo acto concreto de policía o intervencionismo administrativo colectivo tiene que fundarse en un título jurídico igualmente concreto, dado que la idea de reglamentación previa es consustancial con la noción de policía, de tal forma que la Administración, para forzar al administrado al cumplimiento de un determinado deber, tiene que estar autorizada para ello por una norma jurídica, como así lo establece, con carácter general, el número 5 del artículo $1 .^{\circ}$ del Reglamento de Servicios; de todo lo cual se deriva que no existiendo precepto legal alguno que autorice a los Ayuntamientos a imponer a un particular un servicio económico, basado en una supuesta obligación de indemnizar los daños ocasionados a una vía pública por el rodaje y parada de autobuses y estacionamiento de equipajes y bultos, es obligado concluir que al efectuar tal imposición es ilegítima y contraria a Derecho por ausencia precisamente de norma que lo exima del campo del Derecho común.

Tercer considerando: Que la aplicabilidad de tales principios generales al caso de autos, no puede ser enervada alegando que el uso efectuado sobre la vía municipal por la empresa recurrente constituyó un aprovechamiento especial que autoriza al Ayuntamiento a imponer la obligación de reparación que se discute, de acuerdo con lo dispuesto en los artículos 445 de la Ley de Régimen local, 1. ${ }^{\circ}$, apartado 4 , y 17 del Reglamento de Servicios y 107 del Reglamento de Bienes de las Corporaciones locales, pues siendo uso común la utilización de una cosa pública que está, sin necesidad de permiso especial, a disposición de todo el mundo, o al menos de un sector no individualizado de personas y uso especial, la utilización de una cosa pública que, en cuanto no implicada en el uso común, después de un permiso especial, es evidente que este último, como nota característica y diferenciadora, supone una previa licencia o autorización en forma tal que, jurídicamente, no puede concebirse un aprovechamiento especial sin la existencia de una norma que lo sujeta a la obtención de un previo permiso y fije y reglamente sus límites y condiciones, como así lo entienden los artículos 59 y 60 del Reglamento de Bienes, por lo que es necesario concluir que, aun admitiendo que el hecho de estacionar vehículos, equipajes y bultos en una vía municipal o en su acera pudiera constituir un aprovechamiento especial, para que tal hecho tuviera repercusión en el mundo del Derecho, sería obligado que, previamente, el Ayuntamiento, a través de la Ordenanza correspondiente y en ejercicio de su facultad de policía, regulare dicho aprovechamiento, señalando los supuestos del mismo, lo condicionare a la obtención de 
un previo permiso o licencia y estatuyera sus posibles consecuencias económicas, y por ello, al no constar en autos que la Corporación demandada, haciendo uso de la facultad que le conceden los artículos citados, hubiere dictado Ordenanza en tal sentido ni sometido a ella a la Corporación, digo a la empresa recurrente, es claro que, conforme a lo expuesto, no puede configurarse el uso efectuado por ésta sobre la acera y calzada de la vía de autos como aprovechamiento especial de los mismos, ni, por tanto, sostenerse la aplicación al caso debatido de los preceptos legales, que, como son los artículos 445 de la Ley de Régimen local y 107 del Reglamento de Bienes, citados por el Ayuntamiento, presuponen precisamente la existencia de un aprovechamiento especial debidamente reglamentado.

Cuarto considerando: Que no es de apreciar temeridad ni mala fe en ninguna de las partes contendientes a los efectos de una especial condena en costas.

Contra la indicada sentencia, la Abogacía del Estado, de conformidad con el Ayuntamiento, interpuso recurso extraordinario de apelación, por no ser posible la apelación ordinaria por la cuantía del recurso, en interés de la ley, a que se refiere el artículo 101 de la Ley de la Jurisdicción contencioso-administrativa, el cual fue resuelto por el Tribunal Supremo en sentencia de 30 de mayo de 1962, estimando el recurso extraordinario de apelación y declarando que el acuerdo del Ayuntamiento de Ribadeo interesando, en vía administrativa, reintegrarse de los quebrantos y perjuicios causados en obras e instalaciones municipales por un uso especial de la vía pública es conforme con las disposiciones administrativas, siendo los considerandos de la misma los siguientes:

Considepando: Que, concretado el problema litigioso en el considerando aceptado, cabe observar que la sentencia recurrida no entró a esclarecer la intensidad del uso de la vía pública, ni la realidad de los deterioros en ella producidos, cuya indemnización acordó el Ayuntamiento, ni la atribución de los mismos a la empresa, que viene obligada por tal acuerdo, sino que, partiendo del supuesto de tales deterioros y atribución del uso intenso, sienta la doctrina de que, para que el Ayuntamiento pueda imponer por sí mismo a un particular un sacrificio económico basado en una supuesta obligación de indemnizar los daños ocasionados en una vía pública sin necesidad de acudir a la Jurisdicción ordinaria, ejercitando la acción de los artículos 1.902 y siguientes del Código civil, tiene que estar autorizado por una norma jurídica; pues, sin negar las indudables facultades que a los Ayuntamintos compete en materia de policía de las vías municipales, todo acto concreto de policía e intervencionismo administrativo coactivo 
tiene que fundarse en un título jurídico igualmente concreto, dado que la idea de reglamentación previa es consustancial con la noción de policía; y afirmando que el Ayuntamiento carece de norma que le exima del campo del Derecho común, concluye calificando la impresión acordada de ilegítima y contraria a Derecho; pero, aun admitiendo como correcta aquella doctrina, esta afirmación y conclusión son erróneas si se conjugan e interpretan rectamente los mismos preceptos citados por la sentencia, pues, como luego se verá, existe la norma que exime al Ayuntamiento del campo del Derecho común, comunicando a su acuerdo la cualidad de acto administrativo sometido a la Jurisdicción contencioso-administrativa.

Considerando: Que las formas de utilización de los bienes de dominio público que aquí interesan y que considera el artículo 59 del Reglamento de Bienes municipales -uso común general y especial y uso privativo- no dependen de la calificación que hagan las Corporaciones, sino de las circunstancias objetivas que concurran en la varia utilización de aquellos bienes; lo que ocurre es que el ejercicio de unos $\mathrm{u}$ otros usos es de diferente trato al intervenir en ellos la actividad de la Administración, y así como el uso común general se ejercerá libremente (artículo 60 de aquel Reglamento), el uso común especial podrá sujetarse a licencia (artículo 61) y el uso privativo ya tendrá que ser necesariamente objeto de concesión administrativa (artículo 62); no es, pues, exacto que la repercusión en el mundo del Derecho de un aprovechamiento especial de un bien público (y tal considera con acierto la sentencia recurrida, como hecho, el aprovechamiento litigioso) depende de que esté o no sujeto a la obtención de un permiso previo, entre otras razones obvias porque tal sujeción es potestativa, según el citado artículo 61 del Reglamento de Bienes municipales, sin que, por no darse la sujeción, pierda aquel aprovechamiento su específico y objetivo carácter; ese es el sentido del artículo 435 de la Ley de Régimen local, al decir que los Ayuntamientos podrán establecer derechos o tasas sobre los aprovechamientos especiales, y el del artículo $1 .^{\circ}$ del Reglamento de Servicios municipales, al decir que los Ayuntamientos podrán intervenir la actividad de los administrados en la utilización especial de bienes de dominio público, regulando después la forma de ejercicio de esa intervención en el artículo $5 .^{\circ}$, que no es precepto general, sino supeditado a la potestativa voluntad o involuntad de intervención administrativa.

Considerando: Que descartada así la tesis de la sentencia recurrida de no considerar el uso intenso de la vía pública por parte de la empresa X como aprovechamiento especial por la razón de no estar condicionado a la obtención de un permiso, entra en franca y clara aplicación el artículo 445 de la Ley de Régimen local, que es el precepto o norma que desvía el acto del Ayuntamiento que fue recurrido del campo del Derecho común para encuadrarlo en el Derecho administrativo; el precepto dice así: «Excepto en los casos en que la imposi- 
ción de derechos o tasas tenga por único fundamento la depreciación o el desgaste extraordinario producidos en las obras o instalaciones municipales, todo aprovechamiento especial que lleve aparejada depreciación continuada o destrucción o desarreglo temporal de aquellas obras o instalaciones estará sujeto al reintegro del coste total de los respectivos gastos de reconstrucción, reparación, reinstalación, arreglo y conservación, sin perjuicio de los derechos y tasas a que diere lugar»; y aplicado este precepto al caso de autos resulta que si la citada empresa, como queda sentado, realizó un aprovechamiento especial, y éste llevó aparejada una depreciación o destrucción en la obra municipal de la calle, las aceras y las alcantarillas, aquel aprovechamiento estará sujeto al reintegro del coste total de su reconstrucción, y si este aprovechamiento estuviere sujeto a derechos o tasas, aquel reintegro sería exigible, sin perjuicio del percibo de éstas; mas si las tasas o derechos tuvieran como fundamento único la depreciación o el desgaste extraordinario producido en las mencionadas obras, entonces entràría en juego la exceptuación, con lo que comienza el artículo 445, y no procedería el reintegro de los gastos de reconstrucción; doctrina esta que, aunque sólo sea incidentalmente, está expresada en la sentencia de este Tribunal de 28 de enero de 1959.

Volvamos ahora al caso de la sentencia del Tribunal Supremo de 17 de abril de 1975 y a la facultad de resarcirse las Corporaciones locales, sin previo pronunciamiento de los Tribunales, de los daños causados por un particular a los bienes de aquélla que sean de dominio público.

Examinada la legislación de Régimen local correspondiente a la utilización, conservación y administración de bienes de domino público: uso común, general o especial, uso privativo y uso normal y anormal a que se refieren los artículos 59 y siguientes del Reglamento de Bienes de las Entidades locales, no se encuentra un precepto claro en cuanto al reintegro, en procedimiento administrativo, del uso común general de los bienes de dominio público, y concretamente de los daños causados a los bienes de servicio público que no provengan de un aprovechamiento especial.

Me explico: está claro, de conformidad con la citada sentencia del Tribunal Supremo de 30 de mayo de 1962, que todo uso especial de bienes de dominio público, o sea de uso y servicio público, todo aprovechamiento especial que lleve aparejada depreciación continuada o destrucción o desarreglo temporal de aquellas obras e instalaciones, estará sujeto al reintegro de los gastos de reconstrucción, reparación, reinstalación, arreglos y conservación, de conformidad con el artículo 445 de la Ley de Régimen local. 
Y el uso privativo y anormal de los bienes de dominio público, que están sujetos a concesión administrativa, también está claro la obligación de resarcir los daños y perjuicios en procedimiento administrativo que se causaran a los indicados bienes o al uso general o servicio que estuvieren destinados.

El propio artículo 107 del Reglamento de Bienes de las Entidades locales manifiesta que la "extinción de los derechos constituidos sobre bienes de dominio público en virtud de autorización, concesión o cualquier otro título y de las ocupaciones a que hubiere dado lugar, se efectuará por las Corporaciones locales, en todo caso, por vía administrativa mediante el ejercicio de sus facultades coercitivas, previa indemnización o sin ella, según proceda, con arreglo a derecho"; pero el texto transcrito habla exclusivamente de la extinción de los derechos constituidos de los bienes de dominio público, pero no se refiere para nada cuando los daños y perjuicios procedan del uso común general de los bienes de dominio público o que no procedan de derechos constituidos sobre los indicados bienes.

Una parte importante de la doctrina -MAYER, HAURIOU, BALLBÉ, Garcf́a Oviedo y Alvarez-GendíN- considera que los bienes de servicio público deben estar sometidos al Derecho administrativo, incluso considera que deben estar sometidos los bienes muebles de servicio público; y como dicen Garcfa Oviedo-Martinez UseRos, esto lleva consigo el poder de policía, o sea el poder de coacción para defensa de los mismos contra manifestaciones de la libre actividad humana.

Se nota la falta en la legislación de Régimen local de un precepto que diga, con carácter general y claramente, que la obligación de indemnizar los daños y perjuicios causados a bienes de dominio público municipales o provinciales serán fijados por el órgano administrativo correspondiente de la Corporación local a que pertenezcan los bienes.

En el uso común general, y aunque parezca incongruente, la indemnización de los daños causados en bienes de uso público no está regulada de una forma clara en la legislación de Régimen local, y como la interpretación de las normas jurídicas no puede dar lugar al absurdo, estando regulada la indemnización por el procedimiento administrativo en los aprovechamientos especiales y privativos de bienes de dominio público, habría que estimar que si las Corporaciones locales pueden reivindicar los bienes de do- 
minio público, con mayor razón pueden exigir la indemnización de daños y perjuicios causados a los mismos, concretamente los de uso público para conservación y policía, cuya conservación y policía son de la competencia de las Corporaciones locales por el artículo 184 de la Ley de Régimen local, aunque este artículo no resuelve el problema de los de dominio público que no sean de uso público, o sea utilizando la interpretación de las normas jurídicas, de conformidad con el título preliminar del Código civil, partiendo del sentido propio de las palabras en relación con el contexto y los antecedentes históricos legislativos, y a su espíritu y finalidad, y a la interpretación analógica cuando ésta no contemple un supuesto específico, pero regule, en cambio, otros semejantes en los que se aprecia identidad de razón; porque de lo contrario, por ejemplo, los daños causados voluntariamente a un parque público municipal o a una calle de uso público, no habría manera de exigirlos en vía administrativa; y estimamos que es lo que hace la jurisprudencia en sentencia del Tribunal Supremo de 22 de enero de 1976, cuando manifiesta la facultad de actuar en vía administrativa en relación a bienes de las Entidades locales por resoluciones administrativas, que tanto pueden dictarse en ejercicio de facultades de recuperación de oficio de dominio público, como de otras de conservación del uso común derivadas de las facultades de policía especial sobre aquél.

La legislación de la Administración central del Estado regula la indemnización de daños y perjuicios a bienes de uso público, en vía administrativa, de una forma concreta según sean los bienes afectados - playas, carreteras, puertos, costas, aguas, etc.aplicables a la Administración local, si les pertenece alguno de estos bienes, que les fuera de aplicación esta legislación, por ejemplo, un puerto o una carretera; y la Ley del Patrimonio del Estado, que también sería de aplicación a la Administración local, de conformidad con la disposición adicional tercera del Reglamento de Bienes de las Entidades locales, en cuanto a la afectación de bienes integrantes del Patrimonio del Estado al uso general o a los servicios públicos, únicamente expresa que los bienes afectados al uso general o a servicios públicos quedan integrados en el dominio público del Estado y Departamento al que corresponda el ejercicio de las competencias demaniales, incluida la conservación y administración de los bienes, lo que también da lugar a interpretar que en la administración y conservación entra el exi- 
gir en vía administrativa la indemnización de los daños y perjuicios causados a los indicados bienes.

Volviendo a la sentencia del Tribunal Supremo de 17 de abril de 1975 , en relación a un cementerio, y concretando en relación a los bienes de dominio público clasificados como de servicio público, estimamos que hace falta una disposición legislativa que incluya lo reconocido por la doctrina y que esté implícitamente reconocido en la voluntad del legislador, que la indemnización de daños y perjuicios causados a los mismos debe exigirse en vía administrativa, si no no habrá forma de exigir que los daños causados (que no sean consecuencia de un aprovechamiento especial que lleve aparejada depreciación continuada o destrucción) en una Casa Consistorial, en un mercado, por ejemplo, con motivo de unas obras de un particular colindante, puedan interesarse en vía administrativa, y lo mismo puede decirse del resto de los bienes de servicio público - mataderos, museos, campos de deporte- e incluso de bienes muebles de servicio público; lo mismo que se exige en vía administrativa por los particulares a la Administración, la indemnización causada a los bienes de los mismos que impliquen destrucción, detrimento efectivo, o requisa de los mismos por razones de orden o seguridad pública, inundaciones, etc., o toda lesión que los particulares sufran en bienes y derechos, siempre que aquélla sea consecuencia del funcionamiento normal o anormal de los servicios públicos, en que la Administración puede resolver en vía administrativa el importe de la indemnización de los citados daños, sin perjuicio de los recursos que determina la legislación vigente ante la Jurisdicción contencioso-administrativa. 


\section{RESEÑA DE SENTENCIAS}

SUMARIO: I. ACTO ADMINISTRATIVO: SUSPENSIÓN DE SU EJECUCIÓN.-II. BIENES: 1. CaminOS RURALES. 2. RECUPERACIÓN ADMINISTRATIVA: CAMINO PÚBliCO.-III. FUNCIONARIOS: 1. PENSIONES: actualizacion: PORCENTAJE de VIUdedad. 2. Personal laboral NO FUNCIONARIO DE AYUNTAMIENTO.-IV. HACIENDAS LOCALES: 1. ARBiTRIO SOBRE SOLARES SIN EDIFICAR. 2. CONTRIBUCIONES ESPECIALES: RENFE.-V. IMPUESTOS DEL ESTADO: SANCIÓN POR OMISIÓN A LAS CORPORACIONES LOCALES. - VI. POLICIA MUNICIPAL: 1. ACrIVIDADES MOLESTAS, INSALUBRES, NOCIVAS Y PELIGROSAS: COMISIÓN Provincial de Servicios Técnicos. 2. Actividades molestas, insaluBRES, NOCIVAS Y PELIGROSAS: INFRACCION DE LAS CONDICIONES IMPUESTAS EN LA LICENCIA. 3. ACTIVIDADES MOLESTAS, INSALUBRES, NOCIVAS Y PELIGROSAS: LICENCIAS: SILENCIO POSITIVO. 4. DERRIBO DE FINCA: LICENCia. 5. LICENCIAS: CARÁCTER REgLAdo. 6. LICENCIAS: PUBLICACIÓN EN LA Gaceta Municipal de un Ayuntamiento. 7. Licencia de PRIMera UtiLIZACIÓN DE EDIFICIOS. 8. RUINA: EDIFICIOS FUERA DE ALINEACIÓN. 9. RUINA INMINENTE. 10. RUINA: IMPOSIBILIDAD DE REPARAR LOS DAÑOS DE LA EDIFICACION POR MEDIOS NORMALES.-VII. PROCEDIMIENTO ADMINISTRATIVO: 1. FALTA ABSOLUTA DEL PROCEDIMIENTO LEgAL. 2. ANUNCIO POCO EXPLfCIT0.-VIII. SEGURIDAD SOCIAL: 1. ACTUACiÓN DE LOS INSPECTORES eN LAS CORPORACIONES locales. 2. AlguaCil DE un Ayuntamiento. 3. Ayuntamientos: PERSonal DE trabajo DisCONTINUO. 4. AYUNTAMIENTOS: LIMPIEZA DE ESCUELAS NACIONALES. 5. SEgURIdad Social Agraria: EXENCIÓN MUNICIPAL.-IX. SOLARES E INMUEBLES DE EDIFICACION FORZOSA: 1. AGRUPACION DE TERRENOS. 2. COMPETENCIA MUNICIPAL PARA RESOlver.-X. TRANSPORTES: SERVICIOS REGULARES DE TRANSPORTE URBANO DE VIAJEROS.-XI. URBANISMO: 1. Facultades del ORgano QUe aprueba los planes. 2. Obligación DE DEMOLER: SUSTITUCIONN POR INDEMNIZACIONN PLAZO PARA EJERCITAR LA ACCIÓN. 3. ZONAS VERDES: INEDIFICABILIDAD. 


\section{ACTO ADMINISTRATIVO}

\section{SUSPENSIÓN DE SU EJECUCIÓN}

Considerando: Que, ciertamente, la suspensión de la ejecución del acto que se somete a la revisión jurisdiccional por las vías impugnatorias del recurso contencioso-administrativo no es medida cautelar o preventiva que deba adoptarse en todo caso de impugnación, ni condicionada, tan sólo, a la previsión de unos perjuicios, porque la forma singular de tutela jurídica que regula el artículo 122 de la Ley de 27 de diciembre de 1956 requiere, para que pueda otorgarse, y en definitiva para excepcionar lo que es regla general, esto es, la ejecución del acto aunque esté subjudice, la previsión de unos perjuicios cuya reparabilidad no resulta factible $u$ ofrezca dificultad; pero tampoco es acertado sostener que la posibilidad de una reparabilidad por vías indemnizatorias, el juego posible, si el recurso llegara a tener éxito, de equivalentes económicos a cargo de la Administración autora del acto, excluye, en todo caso, la suspensión, porque, aparte de que la dificultad de la reparación no cabe excluirla, sin más, por la circunstancia de que el daño o perjuicio que podría derivar de la ejecución sea valorable económicamente, como ha dicho el legislador de la Exposición de Motivos de la Ley, no todos los perjuicios son de fácil conversión en un "quantum» económico equivalente o tienen otra dimensión o efectos difícilmente medibles con criterios económicos o la ejecución comporta un complejo de perjuicios actuales, continuados, difícilmente soportables; por lo que, en cada caso, en atención a las singulares circunstancias concurrentes, deberá estimarse la entidad del daño o perjuicio que si el recurso tuviera que ser estimado se revelaría como ilegítimo $\mathrm{y}$, en contemplación de esta estimación, atenta a la dificultad reparatoria y, en este marco, del carácter soportable o no de situaciones duraderas de detrimento, privación o menoscabo y de la eficacia restablecedora de las medidas "a posteriori», otorgar la preventora medida de las repercusiones perjudiciales que pudieran ocasionarse, en contemplación también del interés público en juego.

Considerando: Que, dejando a un lado todo juicio valorativo acerca de la legalidad del acto recurrido, pues no es éste el momento, ni la instancia judicial, para hacerlo, entraña el Decreto del Alcalde de Tarrasa, en cuanto ha ordenado la clausura o cese de una actividad industrial, unos efectos múltiples en todo el complejo afectado por la clausura, que en modo alguno pueden ser contemplados desde el ángulo único de la evaluación y reparación económica, porque el cese incide, provocando obligadas crisis, en las relaciones laborales de una plantilla de 28 trabajadores y en la continuidad y subsistencia futura de la empresa si contra el implícito juicio que el Decreto encierra, ningún obstáculo insubsanable se opusiera a la regularidad del ejercicio de la 
indicada actividad empresarial, con el efecto consiguiente y también la incidencia grave sobre la pérdida de clientela, complejo de efectos perjudiciales en muy variados ámbitos, que son, al menos, difícilmente reparables, por lo que, en atención a lo que dispone el artículo 122, 2., y sin que, por otra parte, el interés público demande, prioritariamente, solución distinta, pues el principal interés público que pudiera resultar afectado -el de la seguridad- está tutelado, aparte competencia municipal de lo que no hacemos ahora cuestión por la intervención específica de la autoridad con facultades policiales mineras, procede que acordemos, revocando el auto apelado, la suspensión, condicionada, sin embargo, a tenor de lo que establece el artículo $124,1 .^{\circ}$, a caución en cuantia de 500.000 pesetas. (Auto de 9 de noviembre de 1976, Ar. 5.852).

\section{BIENES}

\section{Caminos Rurales}

Según la sentencia de 30 de octubre de 1965 (Ar. 881 de 1966), "La policía de los caminos rurales corresponde a los Ayuntamientos dentro de sus respectivos términos y en ella están comprendidas las medidas necesarias para mantenerlos abiertos al libre tránsito vecinal, atendida su indiscutible condición de bienes de uso público, de acuerdo con los artículos 184 de la Ley de Régimen local y $3 .^{\circ}$ del Reglamento de Bienes de Entidades locales, de 27 de mayo de 1955, por todo lo cual ha de concluirse en pro de la concurrencia de la legitimación activa en el Concejo demandante y se hace preciso proceder al examen de las restantes cuestiones planteadas». (Sentencia de 21 de octubre de 1976, Ar. 5.459).

\section{RECUPERACION ADMINISTRATIVA: CAMINO PÚBLICO}

CoNSIDERANDo: Que son indudables las facultades municipales intervencionistas sobre la propiedad y actividad de los administrados, previstas en nuestro Ordenamiento jurídico local, especialmente la regulada en el artículo 404 de la Ley de Régimen local y 55 del Reglamento de Bienes de las Corporaciones locales de 27 de mayo de 1955, ya que como enseña y proclama una ya nutrida jurisprudencia de nuestro Tribunal Supremo, dada la naturaleza privilegiada y el carácter estrictamente posesorio de la facultad de recuperación administrativa que los citados preceptos conceden -facultad que en esencia constituye una auténtica acción interdictal actuada directamente por la propia autoridad de dichas Corporaciones-, es indudable que su ejercicio lícito viene subordinado a la real existencia de una prueba por la que se demuestre, en primer lugar, la posesión administrativa, sin per- 
juicio de la verdadera naturaleza de su titularidad dominical y, en segundo lugar, que tal uso público haya sido perturbado o usurpado por el administrado contra quien se dirige la acción municipal, recuperación factible y obligada "en cualquier momento», por así disponerlo el Reglamento local, antes citado - sentencias, entre otras, las de 25 de enero, 22 de abril, 18 de junio de 1968,20 y 29 de marzo y 5 de diciembre de 1969, 27 de enero y 4 de julio de 1970, 14 de marzo y 10 de junio de 1974-. (Sentencia de 15 de dicembre de 1976, Ar. 6.013).

\section{FUNCIONARIOS}

\section{Pensiones: actualización: PoRCENTAJE De viUdedad}

ConsIDERANDo: Que la cuestión planteada en el presente recurso consiste en determinar si al proceder a la actualización de la pensión de viudedad de la recurrente, en aplicación del Decreto 3083/70 de 15 de octubre, ha de tomarse en cuenta el porcentaje del 45 por 100 establecido en los Estatutos de la Mutualidad Nacional de Previsión de la Administración Local o el porcentaje inferior del primitivo señalamiento, como se pretende en la demanda.

Considerando: Que el artículo $1 .^{\circ}$ del Decreto 3083/70, a virtud del cual se ha practicado la actualización, excluye de la misma las pensiones concedidas al amparo de condiciones más beneficiosas que las establecidas en las disposiciones actuales, siendo condición más beneficiosa la aplicación de un porcentaje superior al señalado en los Estatutos, por lo que resulta evidente la conformidad a Derecho de la resolución recurrida, ya que hay que presumir, como dispone el artículo 2 del mencionado Decreto, que la recurrente ha optado por acogerse a la actualización del mismo, renunciando - porque tal renuncia le es beneficiosa - a todas las peculiaridades dimanantes de las disposiciones que amparaban su anterior situación.

ConsIDERANDo: Que la jurisprudencia invocada en la demanda, en apoyo de la pretensión que contiene, de que en la actualización se respete el porcentaje primitivo, carece de adecuación al presente caso, pues se refiere a actualizaciones anteriores, como la dimanante de la Ley $108 / 63$, que no contenían la restrictiva regulación a que se ha hecho referencia, establecida en el repetido Decreto 3083/70, de 15 de octubre. (Sentencia de 13 de diciembre de 1976, Ar. 5.500).

\section{Personal laboral no funcionario de ayuntamiento}

Considerando: Que la fijación de las condiciones laborales de todos los trabajadores no funcionarios mediante una reglamentación única aplicable a todo el personal, cualquiera que sea su clase y servicio 
que preste, profesión u oficio, esto es, mediante una reglamentación específica, propia de empresa, que sustituya a las condiciones mínimas laborales establecidas en las distintas reglamentaciones o convenios dados para los sectores o ramos industriales, en atención a las características y analogía de cada uno de los servicios en que trabaja el personal no funcionario con los regidos por reglamentaciones o por convenios colectivos, constituye una aplicación indebida del artículo $3 .^{\circ}$ de la Ley de Reglamentaciones de Trabajo y una unificación de tratamientos laborales diversos contraria a lo que dispone el artículo 353-2) de la Ley de Régimen local, porque aparte lo excepcional de las reglamentaciones de empresa, sólo admisibles cuando lo aconsejen el volumen o las especiales características de los negocios de una empresa repartida o no en todo o en parte del territorio nacional según lo que dispone aquel artículo, no constituye la Administración municipal, el conjunto de sus servicios, gestionados directamente, esto es, todos aquellos que integrados directamente en la organización municipal cuentan con personal obrero, una modalidad empresarial contemplada en el artículo 3. de la Ley de 16 de octubre de 1942 como supuesto excepcional de reglamentación, frente al criterio territorial y sectorial que establece el artículo anterior con un carácter de generalidad. (Sentncia de 20 de octubre de 1976, Ar. 5.819).

\section{HACIENDAS LOCALES}

\section{ARbITRIO SOBRE SOLARES SIN EDIFICAR}

Considerando: Que rechazada por el citado acuerdo de la Delegación de los Servicios de Hacienda, Rentas y Patrimonio de 30 de mayo de 1972, la petición del contribuyente en punto a la solicitada rectificación de la superficie gravada por inedificabilidad parcial del solar, es hora de juzgar inadecuado a derecho dicho pronunciamiento, a la vista de la carencia de todos los servicios municipales de las parcelas 1 a 10, ambas inclusive, integradas en la finca gravada que fueron formadas a raíz de la autorización dada por la Gerencia Municipal de Urbanismo el 9 de mayo de 1967 (folio 110 expte.), carencia de urbanización que pone de manifiesto no sólo las fotografías y acta notarial aportadas por el actor al expediente, sino también la propia comunicación de aquel órgano urbanístico, expedida el 9 de mayo de 1967 y obrante a los folios 114 y 115 del mismo expediente. La exigencia de la condición de solar del terreno para que pueda ser gravado por el arbitrio en cuestión es el requisito de inexcusable observación conforme a la literalidad del artículo 499 de la Ley de Régimen local, que ya la jurisprudencia reiteradamente expresiva de que la no sujeción es en tal caso consecuencia de la razón básica del arbitrio establecido para promover o formular la cuestión urbana -sentencias de 12 de abril de 1956 y 16 de marzo de 1973-. (Sentencia de 6 de diciembre de 1976, Ar. 5.624). 


\section{CONTRIBUCIONES ESPECIALES: RENFE}

ConsIDERANDo: Que si los bienes integrados en la Red Nacional de los Ferrocarriles Españoles, según la modificación introducida en el artículo 1 del Decreto-ley de 19 de julio de 1962 por el de 23 de julio de 1964, conservan los caracteres y condiciones que corresponden a los bienes del Estado con arreglo a las leyes, no es posible establecer distinción sustancial alguna entre los bienes del Estado y los de la RENFE, a efectos de aplicar la exención del apartado a) del artículo 468 de la Ley de Régimen local; aparte de que se llegaría al mismo resultado, por la vía del apartado d) del propio artículo, al tratarse de inmuebles afectos a la explotación del servicio ferroviario, cuya utilidad pública es indiscutible, al igual que su necesaria incorporación al Patrimonio del Estado, si se produjera su desafectación, a tenor del artículo 27 del Estatuto de 23 de julio de 1964; lo que corduce a mantener la sentencia apelada, en lo relativo a la exención aplicada en favor de la RENFE, por la contribución especial por aumento de valor. (Sentencia de 2 de diciembre de 1976, Ar. 5.622).

\section{IMPUESTOS DEL ESTADO}

\section{SANCIÓN POR OMISIÓN A LAS CORPORACIONES LOCALES}

ConsIDERANDo: Que, finalmente, queda por revisar lo que se refiere a la última de las pretensiones que se actúan en la demanda, la referente a la sanción o multa del 50 por $100 \mathrm{y}$, en tal aspecto, el recurso es de acoger, conforme al criterio ya sentado por esta Sala en otras resoluciones, ya que no cabe olvidar que el artículo 85 de la Ley General Tributaria establece que las sanciones correspondientes a infracciones de omisión y defraudación no se aplicarán a las Corporaciones locales cuando presten su conformidad al requerimiento de la Administración para regularizar su situación tributaria, y en este supuesto se trata de una clara infracción de omisión (art. 79 a), núm. $1 .^{\circ}$, de la indicada Ley) y el Ayuntamiento recurrente prestó su conformidad al requerimiento que le hizo la Oficina liquidadora, sin que pueda oponerse a ello el Reglamento de Derechos Reales del año 1959, ya que la multa podría apoyarse en el artículo 115 del Texto Refundido sobre las Sucesiones, pero en éste hay que atender a su disposición transitoria $60^{\circ}$ y la norma citada de la Ley General Tributaria, al ser una ley cuasi-constitucional, es un precepto común aplicable a todos los tributos, sin necesidad de que sea recogida expresamente en los textos particulares, criterio éste que ya se recoge en la sentencia del Tribunal Supremo de 15 de diciembre de 1967. (Sentencia de 26 de noviembre de 1976, Ar. 5.410). 


\section{POLICIA MUNICIPAL}

1. ACTIVIdAdES MOLESTAS, INSALUbRES, NOCIVAS Y PEligRosas: Comisión Provincial de Servicios Técnicos

CONSIDERANDO: Que impugnada la validez de las actuaciones seguidas en el expediente recurrido, se impone examinar con prioridad los vicios formales invocados, analizando la trascendencia sobre la legalidad del procedimiento establecido para la concesión de la licencia de litis, guiándonos como criterio rector al respecto, de la «ratio juris» determinante de la exigencia de la sujeción al régimen de licencia del ejercicio de una actividad sometida a las prescripciones del Reglamento de Actividades Molestas, Insalubres, Nocivas y Peligrosas de 30 de noviembre de 1961, que responden a la finalidad de defender la tranquilidad, seguridad y salubridad públicas, artículo $1,1 .^{\circ}$, del Reglamento de Servicios de las Corporaciones locales; de suerte que todos los requisitos y trámites prescritos para su concesión, desde los que han de observarse en la solicitud inicial de la licencia, hasta el emplazamiento de la actividad, distancias a respetar y medidas correctoras aplicables, artículos $4 .^{\circ}, 7,10^{\circ}$ y $2 .^{\circ} 11,29,32$ y 33 de aquel Reglamento, han de ser interpretados en función de la exigible protección del interés ciudadano afectado por la actividad a desarrallar, protección que se concreta individualmente en los vecinos inmediatos al lugar de emplazamiento, a lo que obedece que no baste la información pública sobre la licencia solicitada, sino que también sea precisa la "notificación personal a los vecinos inmediatos al lugar del emplazamiento propuesto", artículo 30,2 , a), como asimismo que todas las reclamaciones $u$ observaciones que se presenten hayan de ser informadas por el jefe local de Sanidad y los técniços municipales competentes, según la naturaleza de cada actividad, conforme ordena el apartado b) del artículo y número citados, desarrollado más detalladamente por la regla $4 .^{\mathrm{a}}$ del artículo $4 .^{\circ}$ de la Instrucción para su aplicación de 15 de marzo de $1963 \ldots$, procediendo también mantener, por la misma razón, la validez del trámite de la audiencia personal concedida a los vecinos inmediatos, pese a que ni el jefe local de Sanidad ni ningún técnico municipal haya informado sobre la reclamación presentada por el recurrente, pues ha de tenerse en cuenta que esta segunda omisión también podía quedar suplida por el preceptivo dictamen de las ponencias que habían de informar a la Comisión Provincial de Servicos Técnicos; no pudiendo admitirse, por el contrario, la validez del acuerdo de esta Comisión de 6 de diciembre de 1968 (al folio 16 del expediente), pues olvidando que venía obligada a motivarlo (art. 32), no sólo se limitó a calificar de molesta la industria solicitada, sin aclarar la trascendencia de la molestia que pudiera irrogar al vecindario, cuando según el nomenclátor anexo a la reglamentación de tales actividades venía incluida en él con tal carácter, con la clasificación decimal 205 y 339-15, por los con- 
ceptos de producción de polvo, ruidos y vibraciones, lo que obligaba a examinar la pertinencia de adoptar las oportunas medidas correctoras que evitaran tales molestias al vecindario, cumpliendo así lo ordenado en el artículo 11 del Reglamento; sino que también, a mayor abundamiento, en dicho acuerdo se eludió pronunciarse sobre la reclamación que tenía presentada el recurrente, calificando a la repetida industria no sólo de molesta, sino también de nociva para la explotación agrícolaganadera que desarrolla en la finca contigua al emplazamiento de la industria proyectada. (Sentencia de 29 de octubre de 1976, Ar. 5.645).

\section{ACTIVIDADES MOLESTAS, INSALUBRES, NOCIVAS Y PELIGROSAS: INFRACCIÓN DE LAS CONDICIONES IMPUESTAS EN LA LICENCIA}

Considerando: Que la ineficacia «ope legis» de la licencia que hasta 1965 venía amparando el ejercicio de la industria, motivada por el incumplimiento de las condiciones en ella señaladas, justifica suficientemente la clausura acordada por la Alcaldía de Marbella de conformidad con la Comisión Municipal Permanente de aquel Ayuntamiento, en base a los preceptos citados del Reglamento de Servicios de las Corporaciones locales, que son de primordial aplicación al presente caso, si bien su contenido puede indirectamente relacionarse con lo que preceptúan los números 3 , apartado 1 , en relación con el 9, apartados 3 y 8, apartado 1 de las Instrucciones de 15 de marzo de 1963 para aplicación del Reglamento de Actividades Molestas invocados en el fallo apelado.

Considerando: Que de cuanto hemos expuesto se infiere que las resoluciones municipales recurridas no interfieren facultades de calificación de la industria, como erróneamente se dice por la parte actora, sino que se basan en otros criterios, fundamentalmente en el ejercicio de las actividades industriales con la utilización de medios no autorizados en la licencia en que pretendían ampararse, esto es, en el incumplimiento de las condiciones en que aquélla se otorgó. (Sentencia de 27 de noviembre de 1976, Ar. 5.969).

\section{ACTIVIDADES MOLESTAS, INSALUBRES, NOCIVAS Y PELIGROSAS:}

\section{LICENCIAS: SILENCIO POSITIVO}

Considerando: Que, ciertamente, el silencio positivo es en materia de licencias municipales para el ejercicio de actividades sujetas al Reglamento de 30 de noviembre de 1961, posteriormente modificado por el Decreto de 5 de noviembre de 1964, forma tácita que faculta al particular -en este sentido, las sentencias del Tribunal Supremo de 23 de noviembre de 1962, 3 de octubre de 1963, 23 de octubre y 3 de noviembre de 1964, 25 de noviembre de 1966, 2 de abril de 1968 y 30 de 
abril de 1969- para el ejercicio de la actividad, sin que la situación creada por el silencio pueda desconocerse mediante la emisión de un acto posterior, conforme al artículo 369 de la Ley de Régimen local y sin perjuicio de los remedios a la lesividad de los artículos 16, 2, del Reglamento de Servicios de las Corporaciones locales y 172 de la Ley del Suelo; mas para que juegue el silencio tiene que concurrir, junto a la inactividad municipal, la simultánea denuncia de mora ante el Ayuntamiento y la Comisión Delegada de Saneamiento (que asume la competencia atribuida a la Comisión de Servicos Técnicos) y el transcurso del tiempo que dice el artículo 33, 4, de aquel Reglamento, según la redacción dispuesta por el Decreto de 5 de noviembre de 1964, requisitos no concurrentes porque no se ha denunciado simultáneamente la mora. (Sentencia de 22 de octubre de 1976, Ar. 5.567).

\section{DERRIBO DE FINCA: LICENCIA}

Considerando: Que el derecho al derribo por su propietario de una construcción, cuando la misma no está ocupada como en el caso de autos, sólo está supeditado a la obtención de la oportuna licencia o permiso municipal para su demolición, según establecen los artículos 165 de la Ley del Suelo y 21, núm. 1. ${ }^{\circ}$, del Reglamento de Servicios de las Corporaciones locales, sin que tampoco se oponga a ningún precepto legal que lo prohiba, y por ser además una facultad reglada por la Administración su otorgamiento, tenía que ser necesariamente concedido con la fórmula general de sin perjuicio de tercero, y condicionándolo con las prevenciones necesarias para no afectar ni menoscabar los derechos de tercero. (Sentencia de 25 de octubre de 1976, Aranzadi 5.572).

\section{LICENCIAS: CARÁCTER REGLADO}

Considerando: Que en esta materia de concesión de licencias municipales (en este caso el local aparecía ya configurado en la licencia de edificación como destinado a garaje, etc.), el acto licencia, de acuerdo con su naturaleza, postula inmanentemente una obligada adecuación a la norma, no sólo como presupuesto existencial, sino incluso de lícita vigencia; en base de lo cual la jurisprudencia ha declarado reiteradamente - sentencias de 13 de octubre de 1966, 15 de junio de 1971, 13 de diciembre de 1973, 26 de junio y 24 de octubre de 1974 y 25 de febrero de 1976, etc.- el carácter reglado de esta actividad municipal que propiamente consiste en conceder o denegar la licencia pedida, según que lo instado se acomode o aparte de la solución ofrecida por las normas legales o reglamentarias aplicables, ya que éstas son preceptos terminantemente encauzadores de sus facultades, dentro de cuyos límites ha de resolverse; deviniendo, en consecuencia, obligada 
la concesión cuando la petición del particular reúna los requisitos objetivos exigidos, en cuanto adecuada a ley u ordenanza vigente en el momento de la iniciación del procedimiento. (Sentencia de 8 de noviembre de 1976, Ar. 5.808).

El otorgamiento de licencia para obras y construcciones en terrenos privados es un acto de la Administración en el que ésta se limita a controlar si tal modalidad de ejercicio de las facultades dominicales del particular se ajustan a las disposiciones que lo encauzan y regulan en interés público, en los aspectos urbanísticos, higiénico, ornamental y otros de clara relación con el bien general; disposiciones a las que los Ayuntamientos habrán de ajustarse en el doble sentido de tener que denegar las licencias a que tales disposiciones se opongan y de tener que conceder las que a las mismas se acomodan - sentencia de 31 de octubre de 1958-, sin que, por regla general, pueda rehusar la Administración la concesión de licencias cuando los peticionarios hayan cumplido los requisitos administrativos y fiscales pertinentes -sentencia de 2 de octubre de 1957-, y las licencias son, por tanto, actos administrativos reglados en cuanto a su otorgamiento, pues la concesión de licencias para edificar no son actos discrecionales de la Administración, porque en la hipótesis contraria quedaría reducido a mera entelequia el derecho que, como accesorio del dominio, concedía a todos sus titulares el artículo 388 del Código civil -sentencia de 29 de diciembre de 1956-, y en este fundamento se apoyan también diversas sentencias que declaran que el otorgamiento de licencia municipal para obras y construcciones en terrenos privados no es un acto discrecional, sino reglado, de la Administración, y lo mismo para obras en terrenos de dominio público si antes se ha adquirido derecho de aprovechamiento del mismo - sentencias de 31 de octubre de 1958, 9 de febrero de 1959 y 10 de noviembre de 1960-, y esta doctrina jurisprudencial no ha sido modificada por el cambio que la Ley de la Jurisdicción Contencioso-administrativa de 27 de diciembre de 1956 ha introducido en la doctrina de la discrecionalidad administrativa. (Sentencia de 25 de noviembre de 1976, Ar. 5.958).

\section{Licencias: publicación en la GaCETa Municipal DE UN AYUNTAMIENTO}

Por lo que teniendo por destinatario una pluralidad indeterminada de sujetos resulta preceptiva la publicación, que debe contener los requisitos exigibles en toda notificación, y a los que se refiere el artículo 401 de la Ley de Régimen local y 311 de su Reglamento de Organización, Funcionamiento y Régimen jurídico en relación con el 80 de la Ley de Procedimiento administrativo; de lo que se infiere que hasta que la demandante se dio por enterada del acuerdo otorgando la licencia y recurrió en reposición no empezó respecto a la actora a producir 
los efectos legales pertinentes, entre ellos los referentes al derecho a recurrir, núm. 2. ${ }^{\circ}$ del meritado artículo 401, y 311 del citado Reglamento; sin que pueda estimarse subsanado, por el transcurso de seis meses, la notificación defectuosa, en razón de que al no ser personal, por tratarse de una publicación, no resulta aplicable lo dispuesto en el artículo 79, núm. 4, de la Ley de Procedimiento administrativo, y 311, núm. 2, del Reglamento citado; de todo lo cual se infiere que no puede prosperar la inadmisibilidad del recurso contencioso-administrativo interpuesto, en base a una presunta extemporaneidad de la reclamación formulada en el expediente administrativo, que, de ser acogida por este Tribunal, comportaría el asumir el reconocimiento de que la acción pública establecida en el citado artículo 223 de la Ley del Suelo, por voluntad de la Administración municipal, podrá convertirse en una simple entelequía, quedando sin la debida garantía el interés público a cuya salvaguardia va destinado ese precepto. (Sentencia de 22 de diciembre de 1976, Ar. 6.036).

\section{LICENCIA DE PRIMERA UTILIZACIÓN DE EDIFICIOS}

CONSIDERANDO: Que la inclusión, propugnada por la parte apelante, de los permisos de utilización o de primera ocupación de edificios en

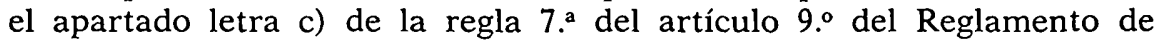
Servicios de las Corporaciones locales, al efecto de entender que se obtienen por silencio positivo mediante el simple transcurso del plazo sin notificar resolución expresa, encuentra el obstáculo de que dicho apartado c), al hablar de "cualquier otro objeto no comprendido en los dos apartados precedentes», exige se trate, como establece con acierto la sentencia apelada, de licencias expresamente comprendidas en la regla $5 .^{\mathrm{a}}$ del precepto analizado, y la de primera utilización no lo está, interpretación que tiene el aval del significado excepcional del silencio positivo que precisa, según el artículo 95 de la Ley de Procedimiento administrativo, de su expresa determinación por la oportuna disposición del ordenamiento jurídico que constituya así excepción al régimen general del silencio administrativo de signo negativo; a lo que ha de añadirse que, íntimamente conectado este tipo de licencias con las de obras o edificación de las que vienen a ser complemento, cual pone de relieve el artículo 21, 2, d) del mismo Reglamento de Servicios al marcar su contenido, el régimen del silencio administrativo habrá de ser el mismo que corresponda a la licencia de obras de la que traen causa. (Sentencia de 22 de diciembre de 1976, Ar. 6.034).

\section{RUINA: EDIFICIOS FUERA DE ALINEACIÓN}

Verdad es que la infracción del ordenamiento urbanístico es una de las hipótesis motivadoras de la declaración de ruina, pero no se 
puede negar que es una hipótesis muy específica, en el sentido de que, a diferencia de las otras dos, que actúan, cada una de ellas, por sí y con independencia de las otras, la situación de "fuera de ordenación" justifica la misma declaración, en función de las otras, es decir, cuando el estado del inmueble requiere la realización de obras que rebasen lo dispuesto en el artículo 48 de la Ley del Suelo, pues cuando bastan los de "pequeña reparación», el apartado c) del 170 no puede entenderse en el sentido de crear una ficción legal de ruina inexistente, en tanto que la realización de los objetivos urbanísticos tiene su tratamiento por otros medios legales - sentencias de 27 de abril de 1973, 12 de febrero de 1973, etc.-. (Sentencia de 20 de octubre de 1976, Ar. 5.457).

\section{RUINA INMINENTE}

Considerando: Que la declaración del estado ruinoso exige, a tenor del artículo 170 , núms. $10^{\circ}$ y $4 .^{\circ}$, de la Ley del Suelo, la audiencia de los interesados, requisito de procedimiento por otra parte general, pero del que dispensa dicho precepto cuando por la inminencia de la ruina el peligro inmediato no permita la demora exigida por ese trámite $y$, como consecuencia, faculta a la Administración para ordenar el desalojo de los ocupantes, lo que en otro supuesto es competencia de los Tribunales civiles, aunque con base en aquella declaración, a tenor del artículo 114, núm. 110, de la Ley de Arrendamientos urbanos; decisiones aquellas que por constituir una evidente merma e incluso sacrificio de derechos de particulares, sólo se legitiman en los estrictos supuestos previstos por la Ley en aplicación de potestades excepcionales para los casos y situaciones de urgencia en el Derecho, por lo cual su aplicación se revelará ilegal si esa situación de urgencia y peligro no concurre por no ser inminente la amenaza de desplome de la edificación. (Sentencia de 20 de octubre de 1976, Ar. 5.456).

Considerando: Que la omisión de la previa audiencia en el procedimiento de ruina y el desalojo administrativo urgente de los ocupantes, previstas, aquélla, en el apartado $10^{\circ}$ del artículo 170 (ahora 183) de la Ley sobre Régimen del Suelo y éste en el apartado $4 .^{\circ}$ del mismo artículo, suponen medidas de excepción que tienen su inmediata justificación en situaciones de inminente peligro, que no permiten esperar el tiempo preciso para la audiencia, o que no admiten demoras en el desalojo; medidas que, por tanto, podrán justificarse si la audiencia se ha omitido, porque, de no hacerlo, la necesidad de invertir tiempo en ella hubiera significado un daño que estaba para suceder prontamente, o si el desalojo tuvo que adoptarse como medida urgente de seguridad en evitación de un peligro que no permitía, razonablemente, acudir a los normales cauces procedimentales; de modo que una y otra medida, como ya tuvimos que decir en la sentencia de 19 de mayo de 1976, han de reputarse como excepcionales e insertarse en el cua- 
dro de decisiones urgentes en atención a exigencias de seguridad y reputarse legítimas cuando razonablemente la proximidad de un peligro, y precisamente para prevenirlo, no permite acudir a las soluciones normales. (Sentencia de 23 de diciembre de 1976, Ar. 6.039).

\section{RUINA: IMPOSIBILIDAD DE REPARAR LOS DAÑOS DE LA EDIFICACION POR MEDIOS NORMALES}

Considerando: Que la no reparación de los daños por medios técnicos normales constituye el supuesto previsto en el apartado A) del número $2 .^{\circ}$ del artículo 170 de la Ley de Régimen del Suelo, para que proceda la declaración de ruina; siendo la jurisprudencia la que ha configurado el concepto de daño no reparable técnicamente por medios normales, siempre que se trate de reconstruir, o sea, sustituir elementos sustanciales de la edificación, requiriéndose, por consiguiente, para ello dos requisitos, a saber, que sea necesario derribar para reponer y que la sustitución se refiera a elementos esenciales de la construcción, es decir, los estructurales que la dotan o contribuyen a su seguridad o consolidación, como ocurre con los que afectan a paredes maestras, muros, techumbres, cubiertas, suelos y sustentación entre otros, pues la reconstrucción y consolidación son medios anormales o excepcionales que no pueden equipararse a reparaciones ordinarias o normales para su conservación o reforma, y aunque lo reconstruido solamente afecte a una parte de lo edificado, no es óbice para declararlo en ruina, puesto que no se necesita que estén ruinosos todos y cada uno de sus elementos y dependencias, siendo suficiente con que la misma le afecte en su unidad funcional, siempre que las partes dañadas puedan influir en la estabilidad y seguridad de su construcción. (Sentencia de 15 de noviembre de 1976, Ar. 5.887).

\section{PROCEDIMIENTO ADMINISTRATIVO}

\section{Falta absoluta del PROCEDimiento Legal}

CONSIDERANDO: Que entrando de lleno en la cuestión de derecho material, de la contemplación del artículo 47 , número $1 .^{\circ}$, letra c), de la Ley de Procedimiento administrativo, tan sólo declara la nulidad de los actos de la Administración dictados prescindiendo total y absolutamente del procedimiento establecido para ello, expresión pleonástica que sólo consiente la invalidez plena del acto cuando concurra la carencia entera y completa de los trámites procesales señalados para su producción, con lo que tampoco basta a la configuración de la Ley defecto u omisión parciales de lo normado; de donde se sigue que toda supuesta nulidad sólo cabe decretarla en aquellos casos en que la concurrencia de gravísimas infracciones legales producen de suyo la inva- 
lidez, delicada materia ésta que requiere tratamiento adecuado con signos y escrúpulo especial, como dicen, entre otras, sentencias de este Alto Tribunal de 12 de diciembre de 1961, 27 de junio de 1972, 30 de septiembre y 3 de noviembre de 1964. (Sentencia de 10 de diciembre de 1976, Ar. 6.002).

\section{ANUNCIO POCO EXPLf́cito}

Considerando: Que no ocurre lo mismo con el otro motivo en el cual la sentencia fundó el esgrimido pronunciamiento de inadmisibilidad atendiendo al hecho de que la publicación del acto impugnado en el Boletín Oficial de la Provincia y en el tablón de anuncios municipal había tenido lugar varios meses antes de la interposición del recurso de reposición y cuando por tanto ya había transcurrido el plazo legal para ello, porque para que efectivamente pudiera entenderse caducado aquél, el acuerdo debería haberse publicado con los requisitos indispensables para ser identificado en su contenido resolutorio, es decir, una publicación "lo suficientemente clara, precisa y comprensiva del contenido del acto o acuerdo a que se da publicidad", tal como dice la sentencia de esta Sala de 21 de mayo de 1973, o dando idea suficiente de los proyectos autorizados, como sienta la de 27 de junio de 1975, lo que evidentemente es compatible con que se hiciese en extracto -según lo permitido por los artículos 213, 241 y 242 del Reglamento de Organización y Funcionamiento-, toda vez que éste ha de ser, cuando menos, suficiente para conocer su contenido y redactado «en forma concisa y clara», según el propio artículo 24.1..$^{\circ}$, circunstancias que evidentemente no se dan en el caso. (Sentencia de 21 de diciembre de 1976, Ar. 6.031).

\section{SEGURIDAD SOCIAL}

\section{ACTUACIÓN DE LOS INSPECTORES EN LAS CORPORACIONES LOCALES}

ConsIDERANDo: Que no es admisible la impugnación formal aducida con apoyo en lo dispuesto en el artículo 661 de la Ley de Régimen local, ya que hay que atender al régimen jurídico previsto en la Ley ordenadora de la Inspección de Trabajo de 21 de julio de 1962, en cuyo artículo $1^{\circ}-2$ sólo excluye la intervención de la función inspectora en los supuestos específicamente excluidos (por falta de competencia), sin indicar expresa ni implícitamente que la inspección deba sujetarse a procedimiento distinto en las visitas que se efectúen a los entes locales; por otro lado, el artículo $2 .^{\circ}, 1$, a, incluye de forma expresa dentro del ámbito de la inspección «a los Centros regidos por el Estado..., Municipio...", sin subordinar la actuación de la inspección al requisito 
de la previa notificación al Alcalde, porque, entre otras razones, perjudicaría la eficacia práctica de la visita y supondría un privilegio innecesario en relaciones jurídicas ajenas a la actividad administrativa de la Corporación. (Sentencia de 2 de noviembre de 1976, Ar. 5.753).

\section{Alguacil de un Ayuntamiento}

Considerando: Que en cuanto al fondo de la cuestión planteada y partiendo del hecho jurídico aceptado por ambas partes de que el señor M. R. presta sus servicios de alguacil por cuenta del Ayuntamiento demandante en virtud de contrato y aunque se precisan las características concurrentes: corporación muy modesta, prestación discontinua del servicio, sin sujetarse a horario ni implicar dedicación primordial o permanente (en realidad sólo trae y lleva la correspondencia, recoge firmas, citaciones y similares), dado su oficio habitual y permanente de labrador autónomo, afiliado a la Mutualidad Agraria con el número 49/1788, no puede legalmente sostenerse otra conclusión que la obligatoriedad de la afiliación y consiguiente cotización al Régimen General de la Seguridad Social. (Sentencia de 9 de noviembre de 1976, Aranzadi 5.855).

\section{Ayuntamientos: PERSonal de trabajo discontinuo}

CONSIDERANDo: Que el hecho de la dedicación no principal y de carácter discontinuo no altera la conclusión establecida, ya que a diferencia de lo que ocurre en el Régimen Especial Agrario, que exige para la inclusión los requisitos de habitualidad y medio fundamental de vida -artículo 2., Ley 31-5-66-, en el General, dada la amplitud del precepto, tal nota no dispensa o excluye de la aplicación, tal como ha declarado la doctrina de la Sala contenida en las sentencias de 4 de octubre de 1975, 22 de octubre de 1976, etc., sin perjuicio de que pueda y deba continuar afiliado como autónomo al Régimen Especial Agrario por no existir incompatibilidad legal, dado que se trata de diferentes trabajos u ocupaciones (artículo $8 .^{\circ}$ de la Ley) que permiten la afiliación múltiple y sin que la especial manera en que se desenvuelve el productor en cuanto al hecho de la prestación y de la remuneración pueda estimarse hoy - como en su día declaró la Sala en sentencias de 30 de enero de 1970 y 27 de mayo de 1971- como bastantes a efectos de una declaración de exclusión por no caber notoriamente dentro de los moldes de los apartados a) y b) del número 1 del artículo 62 de la Ley; y sí sólo podría la Corporación demandante plantear la cuestión al amparo de lo previsto en el número 3 del artículo 62 de la Ley, cuando permite al Gobierno, a propuesta del Ministerio de Trabajo, oída la Organización Sindical y a instancia de los interesados, excluir del Régimen General de la Seguridad Social a las personas cuyo trabajo por 
cuenta ajena, en atención a la jornada o en retribución, pueda considerarse marginal y no constituye medio fundamental de vida. (Sentencia de 2 de noviembre de 1976, Ar. 5.753).

\section{AyUNTAMIENTOS: LIMPIEZA DE ESCUELAS NACIONALES}

Considerando: Que la temática jurídica que plantea este proceso se limita a determinar, por razones de derecho material, la legalidad de la Resolución de la Dirección General de Seguridad Social de 29 de febrero de 1972 en cuanto confirma la decisión de la Delegación Provincial de 19 de mayo de 1971, y en consecuencia declara válida y eficaz en derecho el acta de liquidación número 202/1971, levantada al Ayuntamiento demandante, y por un importe de 92.736 pesetas, por falta de aplicación y cotización a los seguros sociales de productora - limpiadora adscrita a un grupo escolar-, que según la tesis actora no posee vínculo laboral alguno con la Corporación demandante, ya que el desempeño de las labores de limpieza que viene realizando en unas escuelas nacionales y de este territorio no guarda relación jurídica directa con el Ayuntamiento postulante, por cuanto la productora no tiene relación contractual laboral ni de ninguna índole con la Corporación, ni siquiera la conoce, ni presta su cometido o labor bajo la dirección o vigilancia de un empleado o autoridad municipal, puesto que el empleo de ocupación le fue atribuido por el director de la escuela (funcionario estatal), de quien percibe la remuneración correspondiente y de quien recibe, asimismo, las instrucciones en cuanto a jornada, horario y desarrollo de la misión o trabajo, que dada su entidad no absorbe ni en una mínima parte una jornada laboral completa, ni tampoco se destaca la tesis de una actuación autónoma; esto es, se realiza el cometido de limpieza por una cantidad alzada mensual o anual, en forma que por su contenido resulta divergente de la de un trabajador normal incluido dentro de los principios de nuestro Derecho laboral -artículo $10^{\circ}$ de la Ley de Contratos de Trabajo- y preceptos concordantes en el sentido atribuido por la sentencia de la Sala de 4 de octubre de 1975 y la norma contenida en el apartado c) del artículo $1 .^{\circ}$ de la Orden de 31 de diciembre de 1959 exceptúa del régimen general de aplicación dicho a quienes (personal) no tengan vínculo laboral por desempeñar algún servicio determinado que por la forma independiente de su prestación, índole profesional del mismo, forma de retribución, asimilado al concepto de honorario u otras de carácter similar, determine la inexistencia de aquel vínculo; precepto excluyente éste que en alguno de sus supuestos cabe encuadrar el caso discutido, ya que falta aquí indudablemente el desempeño de cometidos laborales bajo la dependencia municipal; ni siquiera puede hablarse de interés directo municipal en el asunto, ni que el ejercicio de tal actividad aparezca inserto dentro de la organización municipal, al existir tan sólo una carga legal de abonar determinada cantidad para 
sufragar el servicio (ni siquiera el coste real), cuya implantación y funcionamiento escapa de las obligaciones impuestas por ley a la propia Corporación; por ello y porque la materialidad de la ocupación presenta características especiales (no sólo por la corta duración, etc.) que permiten pensar en un desempeño como actividad independiente (por horas o tanto alzado) que excluye notoriamente y frente al Ayuntamiento de la existencia de la relación laboral precisa para que la Corporación demandante tuviere que abonar los salarios y las cargas legales derivadas de ellos, como es la cuota empresarial de la Seguridad Social. (Sentencia de 19 de octubre de 1976, Ar. 5.373).

\section{SEguridad Social Agraria: eXeNCión municipal}

Considerando: Que sobre el tema jurisdiccional debatido en este proceso ha sido elaborada con absoluta unanimidad y reiteración, por las Salas cuarta y quinta de este Alto Tribunal, una doctrina estableciendo el criterio de que no son imputables a los Ayuntamientos titulares de los montes públicos de aprovechamiento maderero o resinero, las cuotas de la Seguridad Social Agraria cuando dichos Ayuntamientos demuestran que no explotan en régimen de empresa agraria dichos predios forestales, los cuales, en orden a su conservación, dependen del Patrimonio Forestal del Estado o de los servicios del ICONA, y su explotación maderera o de la resina, en su caso, se efectúa por empresas industriales sometidas al Régimen General de la Seguridad Social. A vía de ejemplo pueden citarse entre las numerosas resoluciones jurisprudenciales expresivas de dicha doctrina las sentencias de 9 de junio de 1970, 23 de marzo de 1971, 27 de diciembre de 1972, 5 de junio de 1973, 9 de junio, 2 de octubre y 21 de noviembre de 1975, etc. (Sentencia de 7 de diciembre de 1976, Ar. 6.000).

Se trata de finca en la que no realiza labor alguna ni tiene personal obrero ocupado en actividades agrícolas o forestales, efectuando por imperativo legal la enajenación de los aprovechamientos forestales mediante subasta pública, como consecuencia de lo cual es el adjudicatario o rematante quien ha de ejecutar, por sí o por las personas asalariadas a su servicio, todos los trabajos de corta y transporte, estando a cargo del Distrito forestal la gestión técnica y la vigilancia, así como también la regeneración del monte; alegaciones que han de ser estimadas por la Sala, atendida la reiterada jurisprudencia - sentencias, entre otras, de 23 de marzo de 1971, 16 y 27 de diciembre de 1972, 4 y 8 de abril de 1974, 19 de febrero, 9 de mayo, 1 de julio y 20 de octubre de 1975,6 y 29 de abril, 8 y 10 de mayo y 6 de diciembre último, etc.-, en las que se declara la no sujeción de los Ayuntamientos y Juntas Vecinales al pago de la cuota empresarial al Régimen Especial Agrario de la Seguridad Social, al no ostentar el carácter de empresario a los efectos de la Ley de 31 de mayo de 1966. (Sentencia de 21 de diciembre de 1976, Ar. 6.033). 


\section{SOLARES E INMUEBLES DE EDIFICACION FORZOSA}

\section{AGRUPACIÓN DE TERRENOS}

CONSIDERANDO: Que si bien los propietarios de fincas no pueden ser constreñidos a la edificación forzosa mediante las medidas estudiadas, cuando aquéllas no reúnen las condiciones mínimas de edificabilidad, porque falta el presupuesto que hemos dicho, y, por tanto, sólo configuradas las parcelas como solares aptos para la edificación, podrá entrar en juego la figura de la edificación forzosa, sí es posible que propietarios colindantes normalicen o regularicen sus propiedades para que reúnan aquel presupuesto indispensable dicho, objetivo de normalización o regularización que podrá lograrse mediante las operaciones configuradoras precisas, dando vida a parcelas distintas edificables, y será también posible en aquellos supuestos de parcelas con superficie inferior a la mínima o con fachada que no cumple los mínimos, como es el caso de este recurso, que mediante la reunión o agrupación de fincas en una sola se forma una finca urbanística que cumpla las exigencias de edificabilidad, como medio aceptado por los propietarios de poner en condiciones de adaptación a la ordenación vigente las parcelas que, en otro caso, no podrían aprovecharse en los términos que ha querido aquella ordenación; y las fincas resultantes que reúnan las condiciones de edificabilidad podrán someterse al régimen de edificación forzosa, sin que sea obstáculo para la agrupación que las mismas estén arrendadas, porque el instituto de la edificación forzosa lo que pretende es que el suelo destinado a la edificación en la ordenación se aproveche con sujeción a las previsiones urbanísticas, y por tanto, reunidas parcelas que no tenían las condiciones mínimas de edificabilidad en otra que responde, sin propósitos fraudulentos, a las condiciones ahora exigibles, queda sometida, en un todo, al complejo de facultades y deberes regulados en la Ley, o en virtud de la misma por el Plan, como contenido de la propiedad urbanística. (Sentencia de 17 de diciembre de 1976, Ar. 6.022).

\section{COMPETENCIA MUNICIPAL PARA RESOLVER}

Considerando: Que la alegación de que el Ayuntamiento perdió su competencia por transcurrir más de seis meses sin dictarse acuerdo resolutorio y haber lugar, por tanto, a la subrogación a favor de la Comisión Provincial de Urbanismo, de acuerdo con lo dispuesto en el apartado e) del artículo 15 del Reglamento citado (de 5 de marzo de 1964) en relación con el artículo $8 .^{\circ}$, núm. 2 , también debe rechazarse, porque como declara la sentencia del Tribunal Supremo de 22 de enero de 1968, refiriéndose a estos preceptos, «la subrogación urbanística que contemplan no opera automáticamente con pérdida de competencia 
para resolver el asunto por parte del mismo órgano administrativo actuante, sino que la misma está subordinada para urgir en un futuro más o menos próximo a que la autoridad administrativa máxima, si lo estima conveniente, por ser potestativo, a propuesta del Consejo Nacional de Urbanismo así lo acuerda, transfiriendo las necesarias atribuciones de la Corporación municipal a la Comisión Provincial de Urbanismo, pero mientras esto no ocurra, la subrogación no tiene efecto y sigue por lo expuesto el Ayuntamiento tardío en sus resoluciones, siendo competente para pronunciarse debidamente en el asunto que desde un principio era de su pleno conocimiento". (Sentencia de 9 de noviembre de 1976, Ar. 5.851).

\section{TRANSPORTES}

\section{SERVICIOS REgULARES DE TRANSPORTES URBANOS DE VIAJEROS}

Considerando: Que en nuestro ordenamiento jurídico —si en él, a través de un rotundo pronunciamiento, es decir, no por medio de una terminante declaración legal- se configuran los servicios regulares de transporte de viajeros, que son los que se realizan concurriendo los requisitos establecidos en el párrafo segundo del artículo $4 .^{\circ}$ de la Ley de Transportes, como una actividad de servicio público - no de mero interés público- cuya prestación técnica, regular y continua, destinada a los administrados, usuarios del servicio, está gestionada por las Corporaciones locales (artículos $1 .^{\circ}$ de la Ley de Transportes y $1 .^{\circ}$ de su Reglamento) cuando de transportes urbanos se trata, y por el Estado cuando los transportes son interurbanos, a través del Ministerio de Obras Públicas, pudiendo explotarlos directamente o adjudicar su explotación mediante concurso (artículos $5 .^{\circ}$ a $7 .^{\circ}$ de la Ley de Transportes); de esta suerte, ningún particular - persona física o jurídicapodrá explotar una línea si no se ha visto previamente revestido de las limitadas funciones administrativas que legalmente le hayan sido transferidas, transferencia que en los servicios de competencia estatal se realiza por medio de la concesión, a través de la cual el órgano competente -Ministerio de Obras Públicas, según el artículo $6 .^{\circ}$ de la Ley de Transportes - cede al particular una esfera de actuación originariamente administrativa, referida al orden de la gestión, creando en aquél un derecho con carácter "ex novo», reservándose siempre el titular originario de tales funciones públicas la facultad de prestar directamente el servicio (artículos 5. y 11 de la Ley de Transportes) o de proceder, caso de haber recurrido a la gestión indirecta del servicio, al rescate de la concesión (artículos 30 a 32 de la Ley de Transportes), pudiendo obtenerse como conclusión aplicable al caso controvertido, la de que el Ayuntamiento de Palma estaba desarrollando una función administrativa de servicio público cuando concedió a "Salma» la autorización impugnada. 
Tratándose de las Corporaciones locales (dejando a un lado las disposiciones generales de los artículos 30 a 36 del Reglamento de Servicios y las normas que dicho Cuerpo legal dedica a la regulación de la gestión directa, que no es la seguida en el caso enjuiciado), el artículo 113 de dicho Reglamento establece como únicas formas de gestión indirecta las de concesión, arrendamiento y concierto, esto es, no incluye la autorizacion, que, sin embargo, ha sido el acto administrativo a través del cual se ha permitido a "Salma" la explotación del tramo prolongado, lo que pone de manifiesto no sólo el quebrantamiento del precepto invocado, sino también la contradicción que supone emplear la autorización - típico instrumento de la actividad de intervención o policía de la Administración, como indica el artículo 5. de Servicios- para alcanzar fines propios de una función administrativa diferente, la de prestación o de servicio público, fines los de esta función que consisten en la satisfacción de las necesidades de los administrados, como dice el artículo 31, número 1, del Reglamento de Servicios, y que mejor se alcanzan cuando más escrupulosamente se someten las Corporaciones locales a los cauces que el ordenamiento jurídico establece, pues el ineludible cumplimiento de las normas procedimentales garantiza tanto los derechos de los administrados como la justa y adecuada realización del interés público, que es el fin de toda actividad administrativa, y el hecho de prescindir total y absolutamente del procedimiento legalmente establecido - como ha sucedido en este supuesto- provoca la nulidad de pleno derecho del acto recurrido, a tenor del artículo 47, número 1, apartado c), de la Ley de Procedimiento administrativo. (Sentencia de 20 de octubre de 1976, Ar. 5.817).

\section{URBANISMO}

\section{Facultades DEL ÓRgano QUE APRUEBA lOS Planes}

CONSIDERANDo: Que es doctrina general la que sostiene que el órgano administrativo al que corresponde la competencia para la aprobación definitiva del plan, proyecto, etc. -artículo 28 de la Ley-, no se proyecta sólo sobre las deficiencias técnicas que presente el proyecto, sino que abarca todos los aspectos, y entre ellos figura con carácter preferente y principal el examen de la acomodación de las normas, objeto de examen, a las del plan general en que se integra o de la Ley en razón del respeto obligado al principio de legalidad urbanística -argumentos de las sentencias, entre otras, de 25 de marzo de 1966, 29 de octubre de 1967, 29 de enero de 1971, 2 de octubre de 1972, 26 de junio de 1974, 6 de octubre de 1975, 22 de enero de 1976, etc.-; mas en todo caso no se trata del ejercicio de facultades discrecionales, puesto que aun admitiendo en ciertos casos el uso o ejercicio de indudables facultades de discrecionalidad técnica - sentencia de 29 de enero de 1971, etc.-, la Administración viene obligada a una valoración fun- 
dada de los hechos determinantes o presupuestos que condicionan su obrar, de tal modo que cuando sienta unos criterios, como base de decisión, erróneos o no ajustados a la realidad de. los hechos o simplemente su conclusión no resulta armonizable con los juicios técnicos emitidos en el expediente, el criterio o juicio resolutorio puede ser combatido y en consecuencia anulado en esta vía como decisión no ajustada al ordenamiento. (Sentencia de 29 de octubre de 1976, Aranzadi 5.637).

\section{OBLIGACIÓN DE DEMOLER: SUSTITUCIÓN POR INDEMNIZACIÓN:} PLAZO PARA EJERCITAR LA ACCIÓN

ConsIDERANDO: Que no pueden ser confundidas, ni por tanto asimilarse en punto a plazo de prescripción, la acción de resarcimiento derivada del daño a que se refiere el artículo 1.902 del Código civil, y a la que el 1.968, núm. 2. ${ }^{\circ}$, asigna el de un año, con aquella cuyo ejercicio tiende a obtener la indemnización señalada en el artículo 228, número 2, de la Ley del Suelo de 12 de mayo de 1956, la cual, y para los supuestos contemplados por los presentes autos, no significa otra cosa que conversión operada en fase ejecutiva de sentencia del objeto o contenido de la obligación de demoler impuesta al condenado en ejecutoria cuyo cumplimiento en sus propios términos quedó enervado al interferirse en la ejecución motivos de interés público determinantes del mantenimiento de la obra y positivamente apreciados por acuerdo de la Comisión Provincial de Urbanismo, tal como al respecto autoriza el número $10^{\circ}$ del citado precepto de la Ley del Suelo, y pues la acción tiene por finalidad dar efectividad, por sustitución, a la ejecutoria recaída, por lo que arrancando de ésta una acción de carácter personal, para lograr su cumplimiento, y no habiéndose fijado en la Ley un plazo especial para su ejercicio, es manifiesto que el tiempo para su prescripción no puede ser otro que el de quince años establecido en el artículo 1.964 del expresado Código. (Auto de 20 de octubre de 1976, Aranzadi 5.818).

\section{ZONAS VERDES: INEDIFICABILIDAD}

CONSIDERANDO: Que el «terrenon donde el recurrente pretende edificar no es "solar»y, por tanto, no es una superficie urbana apta para la edificación, pues el Plan Comarcal, aprobado por la Ley de 3 de diciembre de 1953, asignó a la «zona» donde está situado aquel terreno la calificación de "parque urbano", suelo inedificable, esto es, "zona verde destinada a uso público», según recoge el artículo 56 de las Normas del Plan Comarcal; y es que sólo el "suelo urbano» (artículo 63, número 2, de la del Suelo), que, por su destino en la ordenación, es «edificable» (de edificación pública o de edificación privada) y cuenta 
con los elementos de urbanización (artículo 63, número 3), podrá ser "edificado»; pero no el destinado en la ordenación a "viales» (dedicados a calles y plazas) y a "parques" y "jardines», que, justamente por su destino, están excluidos de "edificación» y afectados, mientras la ordenación urbanística mantenga esta calificación, a aludido destino. (Sentencia de 11 de diciembre de 1976, Ar. 6.004).

NeMESIO RODRfGUez MORO 